\title{
PELANGGARAN HAK CIPTA ATAS KARYA LAGU DAN MUSIK \\ DALAM BENTUK PENJUALAN VCD ATAU DVD BAJAKAN DI YOGYAKARTA
}

\author{
Dewi Prapmasari \\ E-mail: dewi.prapmasari97@gmail.com \\ Mahasiswa Fakultas Hukum Universitas Sebelas Maret Surakarta \\ M. Hudi Asrori S. \\ E-mail: hudisayuti@gmail.com \\ Dosen Fakultas Hukum Universitas Sebelas Maret Surakarta
}

\begin{abstract}
This article aims to determine the perceptions of sellers and buyers about the sale of pirated VCD DVDs regulated in Law No. 28 of 2014 concerning Copyright and to know what factors can improve their legal protection.. The research methodology used is empirical research, namely secondary data published, for further research on primary data in the field or for the community. Legal research materials used are primary and secondary legal materials, techniques used in collecting legal materials are observation, interviews and study of documents or library materials. The results of the research show that the Copyright Law makes songs and music works as one of the protected creations, but there are still many people who do copyright by trading pirated DVDs or VCDs. The perception of the seller who is related to the Copyright Law concerning the need for the Act so as not to involve copyrighted parties, but there must also be a policy that no related party sells pirated VCDs or DVDs. In law enforcement the Copyright Act has several inhibiting factors, namely the legal factors themselves, law enforcement factors, facilities factors, community factors, cultural factors.
\end{abstract}

Keywords: Offense; Copyright; Pirated VCD or DVD.

\begin{abstract}
Abstrak
Artikel ini bertujuan untuk mengetahui persepsi para pelaku jualbeli mengenai penjualan DVD atau VCD bajakan yang diatur dalam Undang-Undang Nomor 28 Tahun 2014 tentang Hak Cipta dan mengetahui faktor-faktor apa saja yang menghambat perlindungan hukumnya. Metodologi penelitian yang digunakan adalah penelitian empiris, yaitu meneliti data sekunder pada awalnya, untuk kemudian dilanjutkan penelitian terhadap data primer di lapangan atau terhadap masyarakat. Bahan penelitian hukum yang digunakan adalah bahan hukum primer dan sekunder, teknik yang digunakan dalam pengumpulan bahan hukum adalah observasi, wawancara dan studi dokumen atau bahan pustaka. Hasil penelitian menunjukkan Undang- Undang Hak Cipta menjadikan karya lagudan musik sebagai salah satu ciptaan yang dilindungi, namun masih banyak masyarakat yang melakukan pelanggaran hak cipta dengan memperjualbelikan DVD atau VCD bajakan. Persepsi para pelaku jualbeli terkait Undang-Undang Hak Cipta ialah pentingnya keberadaan UndangUndang tersebut agar tidak merugikan pihak pemegang hak cipta, namun perlu ada kebijakan agar tidak merugikan pihak pelaku jualbeli VCD atau DVD bajakan. Dalam penegakan hukum Undang-Undang Hak Cipta terdapat beberapa faktor yang penghambat yaitu faktor hukumnya sendiri, faktor penegak hukum, faktor sarana dan fasilitas, faktor masyarakat, faktor kebudayaan.
\end{abstract}

Kata Kunci: Pelanggaran; Hak Cipta; VCD atau DVD Bajakan. 


\section{A. Pendahuluan}

Indonesia adalah negara hukum bukan negara kekuasaan. Pernyataan tersebut dijelaskan secara eksplisit dalam Pasal 1 ayat 3 UUD 1945. Sebagai negara hukum, Indonesia memiliki banyak sekali ketentuan undang-undang. Salah satu ketentuan undang-undang tersebut adalah Undang-Undang tentang Hak Cipta. Berbicara hak cipta, maka sejatinya hak cipta tersebut masuk dalam lingkup Hak Kekayaan Intelektual (HKI). Sebagaimana halnya merek, paten, disain industri dan rahasia dagang. Secara yuridis formal Indonesia diperkenalkan dengan masalah hak cipta pada tahun 1912 yaitu pada saat diundangkannya Auteurswet (Wet van, 23 September 1912, Staatblad 1912 Nomor 600), yang mulai berlaku 23 September 1912 (Rachmadi Usman, 2003: 56). Namun dengan adanya peraturan maka akan menimbulkan akibat hukum bagi yang melanggar aturan tersebut.

Kasus pelanggaran Hak Kekayaan Intelektual (HKI) di bidang musik atau lagu yang terjadi di tanah air sulit tersentuh oleh sanksi hukum. Dapat dikatakan Indonesia adalah negara surga akan pembajakan, tidak jarang dijumpai penjual Digital Versatile Disc (DVD ) atau Video Compact Disc (VCD) bajakan di pinggiran jalan bahkan tidak tanggung-tanggung para penjual DVD atau VCD bajakan berjualan di dalam mal. Faktor ekonomi menjadi salah satu penyebab maraknya kegiatan penjualan VCD atau DVD bajakan.

Peraturan mengenai Kekayaan Intelektual khususnya mengenai hak cipta diatur dengan Undang-Undang Nomor 6 Tahun 1982 yang kemudian diganti menjadi Undang-Undang Nomor 7 Tahun 1987, kemudian diganti kembali dengan Undang-Undang Nomor 12 Tahun 1997 Undang-Undang tersebut diganti menjadi Undang-Undang Nomor 19 Tahun 2002 tentang Hak Kekayan Intelektual dan terakhir diganti pada tahun 2014 dengan diundangkannya Undang-Undang Nomor 28 tahun 2014 tentang Hak Cipta.

Karya musik dan lagu termasuk karya yang harus dilindungi. Namun, dalam kehidupan nyata mengenai implementasi peraturan perundang-undangan yang berlaku belum cukup untuk mengubah kesadaran masyarakat. Masih banyak masyarakat yang melanggar dengan menjualbelikan VCD atau DVD secara tidak sah.

Di Yogyakarta penjualan VCD atau DVD bajakan masih mudah ditemukan, bukan hanya di pusat kota namun tersebar di seluruh kabupaten di Yogyakarta, dalam penelitian ini penulis mengambil sampel tempat penjualan VCD dan DVD di Pasar Imogiri Yogyakarta dan di Jalan Mataram Kota Yogyakarta.

Berdasarkan uraian di atas artikel ini membahas tentang persepsi para pelaku jualbeli mengenai penjualan DVD atau VCD bajakan yang diatur dalam Undang-Undang Nomor 28 Tahun 2014 tentang Hak Cipta dan mengetahui faktor-faktor apa saja yang menghambat perlindungan hukum pemegang hak cipta atas praktik penjualan VCD atau DVD bajakan.

\section{B. Metode Penelitian}

Jenis penelitian yang digunakan penulis adalah jenis penelitian empiris dengan menggunakan dua sumber data yaitu data primer yang berasal dari masyarakat berupa hasil wawancara dengan lima penjual VCD atau DVD bajakan, lima pembeli VCD atau DVD bajakan dan seorang staf Kantor Wilayah Hukum dan HAM Yogyakarta dan menggunakan data sekunder yang terdiri dari bahan hukum primer berupa Undang-Undang Dasar 1945 Negara Republik Indonesia, Kitab Undang-Undang Hukum Perdata, Undang-Undang Nomor 
28 Tahun 2014 tentang Hak Cipta dan dari bahan hukum sekunder berupa tesis, skripsi, disertasi, buku dan artikel di jurnal hukum yang berkaitan dengan penelitian yang diteliti.

\section{Hasil Penelitian dan Pembahasan}

\section{Hasil Penelitian}

a. Persepsi Penjual Dan Pembeli Mengenai Undang-Undang Nomor 28 Tahun 2014 tentang Hak Cipta

Lokasi perdagangan VCD atau DVD bajakan di Kota Yogyakarta secara terangterangan sudah hampir memenuhi semua pusat-pusat pertokoan dan perbelanjaan, seperti pasar-pasar dan mal. Lokasi tersebut dipilih oleh para pedagang sebab lokasi sangat strategis dikarenakan tidak pernah sepi pengunjung. Para penjual VCD atau DVD bajakan ini memiliki latar belakang pendidikannya rata-rata berpendidikan sekolah dasar hingga sarjana. Dari segi latar belakang sosial ekonominya penjual VCD atau DVD bajakan ini dapat dikategorikan sebagai masyarakat mengenah kebawah. Para penjual VCD atau DVD bajakan ini rata-rata telah melakukan perdagangan mereka kurang lebih 5 (lima) tahun. Lama waktu perdagangan VCD atau DVD bajakan ini rata-rata dimulai dari pukul 10.00 sampai 21.00 sementara itu, yang menjaga kios sebagian besar mereka bukan dari pemilik kios tersebut.

Berdasarkan hasil penelitan penulis di Pasar Imogiri Barat dan Jalan Mataram Yogyakarta ternyata sedikit sekali penjual yang memahami isi dari Undang- Undang Nomor 28 tahun 2014 tentang Hak Cipta mereka hanya mengetahui keberadaan Undang-Undang Hak Cipta atau bahkan hanya pernah mendengar secara tidak sengaja.

Persepsi yang diberikan oleh penjual VCD atau DVD bajakan adalah keraguan mereka terhadap pentingnya keberadaan Undang-Undang Hak Cipta, saat penulis menanyakan terkait perlunya Undang-Undang Hak Cipta para penjual tidak dengan tegas menjawab pertanyaan, namun mereka berpendapat bahwa jika tidak ada Undang-Undang Hak Cipta akan merugikan pihak pencipta atau pemegang Hak Cipta. Sedangkan para pembeli VCD atau DVD bajakan memberikan persepsi bahwasannya penting adanya Undang-Undang Hak Cipta agar tidak merugikan ekonomi pihak pencipta namun harga jual VCD atau DVD orisinal diharapkan tidak terlalu mahal dan salah satu pembeli berpendapat perlu adanya pendidikan sejak dini terkait hak cipta.

b. Pengaturan Perlindungan Hukum Bagi Pemegang Hak Cipta dalam Undang-Undang Nomor 28 Tahun 2014

Perlindungan hukum sebagaimana yang diatur dalam UU No. 28 Tahun 2014 tentang Hak Cipta pada dasarnya dimaksudkan untuk memberikan rasa aman bagi pencipta atau pihak-pihak yang menjadi pemegang hak cipta khususnya dikalangan industri. Pengaturan perlindungan kepada pencipta dan pemegang hak cipta dalam Undang-Undang Nomor 28 Tahun 2014 tentang Hak Cipta (selanjutnya disebut UUHC) sudah mengalami perkembangan yang cukup signifikan dibandingkan dengan undang-undang yang lama. Dalam UUHC Tahun 2014, perlindungan pencipta dan ciptaannya diatur lebih detail dibandingkan dengan UUHC sebelumnya. 
Namun demikian, kenyataan menunjukkan bahwa hingga saat ini berbagai bentuk pelanggaran hukum atas suatu karya cipta seperti peniruan, pembajakan, penjiplakan maupun perbuatan curang lainnya masih sering terjadi di tengah-tengah masyarakat. Kondisi ini dipicu oleh mahalnya produk-produk karya cipta yang asli, terutama dalam bentuk karya lagu dan musik, sehingga sulit terjangkau bagi sebagian kalangan masyarakat Indonesia. Dalam hak cipta lagu terdapat hak ekonomi, yaitu hak untuk memperoleh keuntungan ekonomi atas kekayaan intelektual. Dikatakan hak ekonomi karena hak kekayaan intelektual adalah benda yang dapat dinilai dengan uang. Hak Ekonomi tersebut meliputi hak menerbitkan ciptaan, penggandaan ciptaan dalam segala bentuknya, penerjemahan ciptaan, pengadaptasian, pendistribusian ciptaan, pertunjukan ciptaan, pengumuman ciptaan, komunikasi ciptaan, dan penyewaan ciptaan.

\section{Pembahasan}

a. Persepsi Para Pelaku Jual Beli Mengenai Penjualan DVD atau VCD Bajakan terhadap Undang-Undang Nomor 28 Tahun 2014 tentang Hak Cipta

Penerapan "Teori Fiksi” bagi setiap produk hukum membawa konsekuensi yuridis yang komprehensif, khususnya bagi seluruh masyarakat Indonesia. Seluruh masyarakat dianggap telah mengetahui setiap peraturan perundang-undangan yang telah disahkan oleh Presiden dan telah diundangkan di dalam Lembaran Negara Republik Indonesia. Secara pasti masyarakat tidak dapat menggunakan alasan tidak mengetahui berlakunya suatu peraturan perundang-undangan untuk melepaskan diri dari pertanggungjawaban yuridis atas pelanggaran hukum yang telah dilakukannya (Ali Marwan, 2016: 8).

Seluruh masyarakat dianggap mengetahui berlakunya peraturan perundangundangan merupakan suatu metode untuk memanipulasi tersosialisasinya produk hukum yang pada kenyataannya tidak sesuai. Hal ini berkaitan dengan berlakunya hukum secara sosiologis, yakni apabila kaidah hukum dapat efektif (Soleman B. Taneko,1993: 47). Namun dalam kenyataannya masih banyak peraturan yang belum tersosialisasikan kepada masyarakat.

Berdasarkan hasil penelitian yang telah diuraikan diatas diketahui bahwa upaya komersialisasi terhadap sebuah karya melalui penjualan DVD atau VCD bajakan baik itu di pasar atau di dalam mal. Penjualan DVD atau VCD bajakan ini sangat dipengaruhi oleh kesadaran hukum masyarakat yang masih rendah, Undang-Undang Hak Cipta hendaknya tidak hanya menetapkan tujuan dari undang-undang saja baik dari perspektif kehendak pembuat undang-undang (Soerjono Soekanto, 1988:14-16). Syarat-syarat tersebut berupa perilaku yang diamati adalah perilaku nyata, perbandingan antara perilaku yang diatur oleh hukum dengan keadaan seandainya perilaku tersebut tidak diatur oleh hukum serta mempertimbangkan kesadaran pelaku.

b. Faktor Penghambat dalam Pelaksanaan Perlindungan Hukum Bagi Pemegang Hak Cipta Atas Praktik Pembajakan dalam Bentuk DVD atau VCD

Menurut Soerjono Soekanto penegakan hukum bukan semata-mata pelaksanaan perundang-undangan saja, terdapat faktor lain yang mempengaruhinya yaitu (Soerjono Soekanto, 2005: 17-66) 
1) Faktor Hukumnya

Undang-undang dalam arti materiel adalah (Purbacaraka dan Soerjono Soekanto,1979) peraturan tertulis yang berlaku umum dan dibuat oleh penguasa pusat maupun daerah yang sah. Gangguan terhadap penegakan hukum yang berasal dari undang-undang yaitu karena tidak diikutinya asas-asas berlakunya undang-undang, belum adanya peraturan pelaksanaan yang sangat dibutuhkan untuk menerapkan undang-undang, dan ketidakjelasan arti kata-kata di dalam undang-undang yang mengakibatkan kesimpangsiuran di dalam penafsiran serta penerapannya.

Dalam pelanggaran hak cipta terkait praktik penjualan VCD atau DVD bajakan faktor hukumnya bisa menjadi hambatan bagi penegakan hukum. Menurut penulis Undang-Undang Hak Cipta tidak memenuhi salah satu asas yang telah disebutkan Soerjono Soekanto yaitu undang-undang merupakan suatu sarana untuk mencapai kesejahteraan spiritual dan materiel bagi masyarakat dan pribadi namun kenyataanya UUHC tidak mencapai kesejahteraan materiel bagi penjual VCD atau DVD bajakan, seharusnya UUHC mengategorikan ekonomi penjual, dan memberikan keringan kepada penjual yang memiliki ekonomi mengenah kebawah.

2) Faktor Penegak Hukum

Penegak hukum secara sosiologis mempunyai kedudukan (status) dan peranan (role), kedudukan merupakan posisi tertentu dalam struktur kemasyarakatan. Peranan yang seharusnya dari kalangan penegak hukum tertentu, telah dirumuskan di dalam beberapa undang-undang tersebut juga dirumuskan perihal peranan yang ideal misalnya Undang-Undang tentang Ketentuan-Ketentuan Pokok Kepolisian Negara. Namun terkadang terdapat halangan-halangan yang mungkin dijumpai dalam penerapan peran.

Berdasarkan wawancara penulis dengan penjual VCD atau DVD bajakan mereka hanya mendapatkan satu kali sosialisasi dari kepolisian selama mereka berjualan, hal tersebut menandakan kurang aktifnya penegak hukum untuk memberantas penjualan VCD atau DVD bajakan.

3) Faktor Sarana atau Fasilitas

Faktor sarana atau fasilitas pendukung mencakup perangkat lunak dan perangkat keras, salah satu contoh perangkat lunak adalah pendidikan. Pendidikan yang diterima oleh Polisi dewasa ini cenderung pada hal-hal yang praktis konvensional, sehingga dalam banyak hal polisi mengalami hambatan di dalam tujuannya, diantaranya adalah pengetahuan tentang kejahatan komputer, dalam tindak pidana khusus yang selama ini masih diberikan wewenang kepada jaksa, hal tersebut karena secara teknis yuridis polisi dianggap belum mampu dan belum siap. Walaupun disadari pula bahwa tugas yang harus diemban oleh polisi begitu luas dan banyak. 
4) Faktor Masyarakat

Masyarakat sangat berperan penting dalam penegakan hukum namun terkadang terdapat masalah-masalah yang sering timbul dalam masyarakat yang dapat mempengaruhi penegakan hukum dapat berupa (Soerjono Soekanto,1983:56)

a) Masyarakat tidak mengetahui atau tidak menyadari, apabila hak-hak mereka dilanggar atau terganggu;

b) Masyarakat tidak mengetahui akan adanya upaya-upaya hukum untuk melindungi kepentingan-kepentingannya;

c) Masyarakat tidak berdaya untuk memanfaatkan upaya-upaya hukum karena faktor-faktor ekonomi, psikis, sosial, atau politik.

Faktor masyarakat sangat berpengaruh dalam penegakan hukum bagi pelanggaran hak cipta dalam bentuk penjualan VCD atau DVD bajakan, masyarakat perlu menanamkan kesadaran akan pentingnya menghargai sebuah karya cipta dan penting bagi masyarakat untuk mengetahui sebuah peraturan dan menerapkannya dalam kehidupannya.

5) Faktor Kebudayaan

Kebudayaan menurut Soerjono Soekanto, mempunyai fungsi yang sangat besar bagi manusia dan masyarakat, yaitu mengatur agar manusia dapat mengerti bagaimana seharusnya bertindak, berbuat, dan menentukan sikapnya kalau mereka berhubungan dengan orang lain.

Berdasarkan kasus pelanggaran hak cipta dalam bentuk penjualan VCD atau DVD bajakan faktor kebudayaan tidak terlalu menjadi faktor penghambat dalam penegakan hukum karena pada dasarnya masyarakat Indonesia berbudaya komunal yang artinya memiliki rasa kebersamaan yang tinggi, karena budaya komunal tersebut masyarakat berpendapat karya cipta tersebut bisa dinikmati bersama tanpa harus mengikuti aturan yang berlaku seperti yang telah diatur dalam Undang-Undang Hak Cipta.

\section{Simpulan}

1. Persepsi penjual dan pembeli VCD atau DVD bajakan adalah mereka masih merasa ragu dengan adanya Undang-Undang Hak Cipta karena disatu sisi jika tidak ada penegakkan hukum Undang-Undang Hak Cipta akan merugikan pihak pencipta dan pemegang hak cipta namun disisi lain keberadaan Undang-Undang Hak Cipta menghambatperekonomian mereka. Sedangkan pembeli VCD atau DVD bajakan memberikan persepsi bahwasannya penegakan hukum atas Undang-Undang Hak Cipta sangat diperlukan untuk melindungi hak-hak yang dimiliki pencipta atau pemegang hak cipta bahkan perlu adanya pendidikan sejak dini terkait hak cipta namun para pembeli berharap agar harga jual DVD atau VCD orisinal tidak terlalu mahal.

2. Terdapat faktor-faktor penghambat yang menyebabkan kurang maksimalnya pelaksanaan perlindungan hukum pemegang hak cipta atas praktik penjualan VCD atau DVD bajakan Pertama adalah faktor hukumnya sendiri yaitu tidak diikutinya asas-asas berlakunya 
undang-undang dan ketidakjelasan arti kata-kata didalam undang-undang, Kedua adalah faktor penegak hukum dimana kurangnya sosialisasi dari aparat penegak hukum terutama pihak kepolisian dalam penanganan kasus penjualan VCD atau DVD bajakan, Ketiga adalah faktor sarana atau fasilitas guna mendukung kinerja penegak hukum contohnya pendidikan bagi pihak kepolisisan, Keempat adalah faktor masyarakat dimana kurangnya kesadaran hukum dari masyarakat dan masyarakat kurang menghargai sebuah karya cipta, Kelima adalah faktor kebudayaan yaitu masyarakat indonesia yang bersifat komunal yang artinya mrmiliki rasa kebersamaan yang tinggi dan menganggap karya cipta tersebut bisa dinikmati bersama tanpa membayar royalti ke pemegang hak cipta.

\section{E. Saran}

1. Pemerintah khususnya Direktorat Jendral Kekayaan Intelektual perlu membuat kebijakan yang berpihak kepada masyarakat ekonomi menengah kebawah yang hanya memiliki pekerjaan sebagai penjual VCD atau DVD bajakan namun tidak merugikan pihak pencipta atau pemegang hak cipta dan pentingnya pendidikan sejak dini mengenai sanksi yang akan didapat jika melanggar undang-undang yang telah ditetapkan serta penurunan harga VCD atau DVD orisinal agar dapat dijangkau oleh seluruh masyarakat.

2. Terdapat beberapa faktor penghambat dalam perlindungan hak cipta atas praktik penjualan VCD atau DVD bajakan hendaknya pemerintah dan aparat penegak hukum khususnya kepolisian lebih gencar mengadakan sosialiasi kepada masyarakat atau dengan mengadakan event yang melibatkan para pencipta lagu (workshop, bazar, dan lain- lain) dan bekerja sama dengan organisasi perangkat daerah (OPD) seperti dinas perindustrian, dan dinas perekonomian untuk kemudian memasang atau menyebar slogan-slogan yang bertemakan perlindungan hak cipta dan dalam membuat sebuah aturan, legislator harus memperhatikan faktor yang menjadi hambatan dalam penegakan hukumnya agar terciptanya harmonisasi antara Undang-Undang Hak Cipta dengan kesadaran hukum dan budaya masyarakat sehingga tidak terciptanya gap yang terlalu jauh.

\section{F. Daftar Pustaka}

Abdullah Haniif. 2014. "Faktor Penyebab Dan Penanggulangan Penjualan Vcd Bajakan”. Juranal Ilmu Hukum Legal Opinion. Edisi 2. Volume 2. Palu: Fakultas Hukum Universitas Tadulako.

Akhmad Munawar Dan Taufik Effendy, 2016. "Upaya Penegakan Hukum Pelanggaran Hak Cipta Menurut Undang-Undang Nomor 28 Tahun". Al'adl, Volume Viii Nomor 2, Mei-Agustus 2016. Banjarmasin: Fakultas Hukum Universitas IAIN Kendari.

Nahrowi. 2014. "Plagiat dan Pembajakan Karya Cipta dalam Hak Kekayaan Intelektual. Jurnal filsafat dan Budaya Hukum, Vol. 1 No 02. 19 November 2014. Jakarta: Fakultas Hukum Universitas Islam Negeri Syarif Hidayatullah.

Budi Agus Riswandi. 2009. "Permasalahan Pelanggaran dan Langkah Hukum Hak Cipta Atas Musik Dan Lagu Yang Dituangkan Dalam Bentuk VCD Dan DVD”. Jurnal Hukum Ius Quia Iustum No. 4 Vol. 16 Oktober 2009. Yogyakarta : Fakultas Hukum Universitas Islam Indonesia. 
Dewi Prapmasari, M. Hudi Asrori S. Pelanggaran Hak Cipta atas Karya Lagu dan Musik dalam Bentuk ...

Lope Fransin Miranda.2013. "Penegakan Hukum Terhadap Pelanggaran Hak Cipta di Bidang Musik dan Lagu". Lex Privatum. Vol. 1, No. 2, April- Juni 2013. Hlm. 48-49. Manado: Fakultas Hukum Universitas Sam Ratulangi.

Soerjono Soekanto. 2005. Faktor-Faktor yang Mempengaruhi Penegakan Hukum. Jakarta: PT Raja Grafindo Persada.

Soerjono Soekanto. 2010. Pengantar Penelitian Hukum. Jakarta: UI Press.

Undang-Undang Dasar Negara Republik Indonesia 1945

Undang-Undang Nomor 28 Tahun 2014 tentang Hak Cipta 